\title{
Land use sediment production response under different climatic conditions in an alpine-prealpine catchment
}

\author{
Leticia Palazón* and Ana Navas
}

Department of Soil and Water. Estación Experimental de Aula Dei (EEAD-CSIC), Spain

*Corresponding author: lpalazon@eead.csic.es;

tel.: +34976716143 and fax: +34976716145

\section{Highlights}

SWAT model outputs served to assess sediment yields from different land uses in an alpineprealpine watershed.

Land use-land cover significantly affected sediment productions.

Sediment yields varied between agricultural uses.

Land use responses to a temperature increase of $2^{\circ} \mathrm{C}$ varied largely.

For increases of $2^{\circ} \mathrm{C}$, drier conditions favoured erosion more than wetter. 


\section{Abstract}

Loss of soil and subsequent export of sediments to streamflows by water erosion constitute significant environmental threats because of the areal extent typically involved and the agricultural activities that they support. Climate change is expected to impact on the availability of water and therefore on soil resources. In this context, hydrological and soil erosion models allow for the mapping and quantifying of soil redistribution and sediment productions for different land uses and climatic scenarios that can be used for valuable projections for catchment management. A simulation experiment was achieved by using the Soil and Water Assessment Tool (SWAT ${ }^{1}$ ) model in the mountainous catchment of the Barasona reservoir (1509 $\mathrm{km}^{2}$, Central Spanish Pyrenees), which is characterized by a heterogeneous climate and topography, that brings it a varied mosaic of soil types and land uses. In order to investigate differences in sediment productions from the land uses under different climatic conditions the sediment produced from the land uses was assessed for two years. 2003 and 2005 were selected to represent contrasted precipitations and wet and dry conditions, respectively. Moreover, the distribution of land uses and climate in the catchment enabled the division of the catchment into two parts which allowed the assessment of the sediment productions in the northern alpine and the southern Mediterranean parts of the catchment. The specific sediment yield varied largely in relation with precipitation, seasons, land use types and catchment parts, from 0 to $243 \mathrm{t} \mathrm{ha}^{-1}$ year $^{-1}$. Furthermore, according to the prediction of the IPCC and climatic studies for the region an increase of $2{ }^{\circ} \mathrm{C}$ was simulated to assess the impact on sediment yield. Different responses to the temperature increment were observed between wetter (2003 and northern part) and drier (2005 and southern part) conditions and also for the land use types. Great decreases in sediment production were observed for the $2^{\circ} \mathrm{C}$ increase scenario in wetter conditions, whereas low decreases with some increments occurred in the drier conditions. The proposed model proved useful for the assessment of the behaviour in sediment production from the land uses under different climatic conditions in large alpine-prealpine catchments at a regional level.

Keywords: Soil erosion; Soil erosion models; SWAT; Climate change; Land use; Erosivity

Abbreviations : Soil and Water Assessment Tool (SWAT); Hydrological Response Units (HRUs); temperature lapse rate in SWAT (TLAPS); precipitation lapse rate in SWAT (PLAPS); specific sediment yield from the land uses $\left(\mathrm{SSY}_{\mathrm{LU}}\right)$; scenario with the temperature increase $\left(2^{\circ} \mathrm{S}\right)$; scenario with the observed data (OS); percentage difference (PD) 


\section{Introduction}

The loss of productive soil by water erosion does not only reduce soil quality, but also has important effects on the soil functions such as decreasing their net primary productivity of the agricultural lands and the natural ecosystems (Pimentel, 2006; Stavi and Lal, 2011). Estimates indicate that one-sixth of the global land area is affected by water erosion (Schröter et al. 2005), constituting an important economic, social and environmental problems. In temperate climate mountain areas water induced hillslope erosion is one of the more common forms of erosion (Navas et al., 2005). However, surface runoff, soil detachment and sediment delivery are non-linear processes that depend on many soil, climatic, topographic, vegetation and land use parameters and, furthermore, their effects change when considering different temporal and spatial scales (Cerdà et al., 2013). To develop environmental and land use management plans, policy makers require quantification of erosion rates at regional and global scales, identification of sediment sources and estimates of the relative contribution from the different land uses. Thus, these measurements allow erosion prevention efforts to be concentrated in places that will benefit most (de Vente et al., 2008; Ramos and Martínez-Casasnovas, 2014).

Changes in precipitation, temperature, and vegetation cover alter the water balance and the partitioning of precipitation between evapotranspiration, surface runoff, and groundwater flow (Foley et al., 2005). Variations in a precipitation regime directly affect the quantity of water that reaches the soil, the runoff generation mechanisms, and the magnitude of river discharge. More scattered and intense rainstorms could potentially cause changes in the vegetation cover (Kundzewicz et al., 2007; Nunes and Nearing, 2011). The rise in temperature, together with changes in other parameters (solar radiation, wind speed, and humidity), could decrease the quantity of precipitation falling as snow, accelerating the melting process and consequently reducing the snow duration. It could also increase the transpiration processes in plants as well as evaporation from the soil and water bodies 
(García-Ruiz et al., 2011). All these changes result in water balance disturbances that may alter both the quantity of water in the soils and its temporal distribution, which are highly related to the land uses existing in the contributing areas thus affecting soil erosion and the supply of sediments. Therefore, global climate change has the potential to modify sediment productions and soil erosion depending on the possible changes in climate and the physiographic (e.g. vegetation cover, soil, geology, hydrology and geomorphology) characteristics of the region.

The Fifth Assessment Report of the Intergovernmental Panel on Climate Change (IPCC WGI AR5 2013) summarized that the total increase between the average global surface temperature of the 1850-1900 period and the 2003-2012 period was $0.78(0.72$ to 0.85$){ }^{\circ} \mathrm{C}$, based on the single longest dataset available. For most of the simulated climatic change scenarios, the global surface temperature change for the end of the 21st century is likely to exceed $1.5^{\circ} \mathrm{C}$ in relation to the $1850-1900$ period. In the Central Spanish Pyrenees, the scenarios generated by several climate studies point to a clear increase trend in temperature of about $1.5-3{ }^{\circ} \mathrm{C}$ but the precipitation trend is not clear (e.g. López-Moreno et al. 2008; Ribalaygua et al. 2013).

Due to a variety of land covers, climatic heterogeneity and altitudinal gradients, a great diversity of processes relating to soil erosion and sediment yield occur in the Central Spanish Pyrenees. Furthermore, human activity during the last 4000 years has contributed to the disturbance of the original landscape by changing land uses and therefore its hydromorphological dynamics (Navas et al. 1997; García-Ruiz and Valero-Garcés, 1998, Navas et al. 2008). In addition, many rivers on the Spanish side of the Pyrenees have been dammed in the last century to provide water for the Mediterranean lowland areas (e.g. Yesa and Barasona reservoirs). Hydrologic characteristics of the Spanish Pyrenean and changes in land use over the last few decades have changed the supply of sediment loads (Navas et al. 2011; Morellón 
et al. 2011), triggering soil erosion and, consequently, the derived off-site environmental problems such as the siltation of reservoirs (Valero-Garcés et al. 1999; Navas et al. 2009).

The Pyrenees are a very sensitive area in terms of impacts of climate change on hydrological dynamics and related processes, as water erosion.. Hence, information on processes related to soil erosion and sediment export in mountainous catchments are essential to support the implementation of management practises to preserve soils, to promote rational uses of the land and to prevent erosion (Molino et al. 2007). Catchment models offered an effective way of studying land-surface dynamics in mountain environments and obtaining information on water-induced erosion processes linked to hydrological systems. Moreover, catchment models, like SWAT, make it possible to evaluate the impacts of natural or management induced environmental changes in a way that cannot be done through field experiments and direct observation and as such, constitute as chief tools in developing environmental management plans at a regional scale (e.g. Dessu and Melesse 2012, 2013). Therefore, it could serve as a decision-making tool for performing risk analysis in the implementation of measures to prevent the on-site and off-site effects of soil erosion, and to assess the possible impacts resulting from land use or climate changes.

The SWAT model has been extensively applied throughout the world (e.g. Zhang et al. 2008; Luo et al. 2012; Dessu et al. 2014) to deal with a wide range of scales and issues (Gassman et al. 2007). Although SWAT was primarily built for plain agricultural areas, it has been widely implemented to perform hydrological simulations to estimate streamflow timing and volumes and sediment yield from mountainous catchments worldwide (e.g. Rostamian et al. 2008; Flynn and Van Liew 2011; Morán-Tejeda et al. 2015). However, there are not as many studies assessing the sediment production from different land uses under different climatic scenarios (e.g. Nunes et al. 2008) and none are in the alpine-prealpine catchments in the Pyrenean region. 
A previous satisfactory application (calibration and validation) of SWAT for hydrology and sediment supplies to the Barasona reservoir (Palazón and Navas 2014) proved to be useful for identifying area where significant erosion processes take place in large alpine-prealpine catchments and also for assessing the sediment yields which reach the reservoir. Results from that application encouraged the exploration of the model's performance on sediment yields from the different land uses existing in the catchment for different precipitations, seasons and areas. In this research, two different years with contrasted precipitation amounts (2003 and 2005) were selected to obtain information related to different sediment productions from the land use. Moreover, an increase of $2^{\circ} \mathrm{C}$ was simulated with SWAT to assess how this change of temperature could affect soil erosion and sediment production under different land uses. It was considered that modelling a large mountain catchment such as the Barasona catchment under different climatic scenarios/conditions would be of interest to assess the sediment production and changes in relation to the land uses.

\section{Material and Methods}

\subsection{Study Area}

The Barasona reservoir research catchment $\left(1,509 \mathrm{~km}^{2}\right)$ is located in the central part of the Spanish Pyrenees, in the basin of the upper Cinca River, the second largest tributary of the Ebro River (Fig. 1a). The Barasona reservoir was built in 1932 for irrigation purposes and power generation. It also supplies water to the Aragón and Cataluña canal, which provides irrigation to more than 100,000 ha. Over the past 65 years there has been a considerable loss of storage capacity in the reservoir and siltation management problems (e.g. Navas et al., 1998, 2004; Valero-Garcés et al., 1999). 


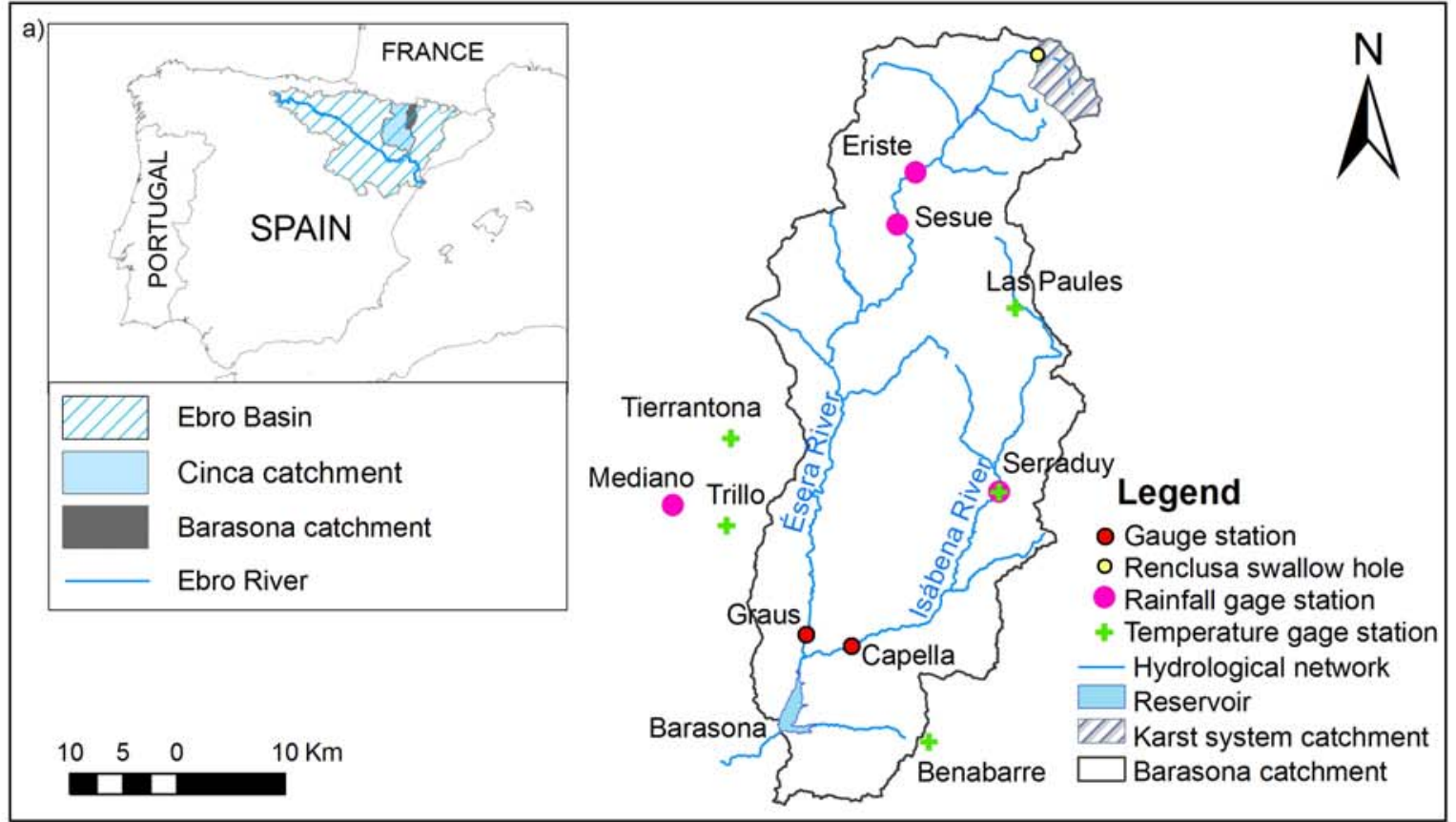

b)
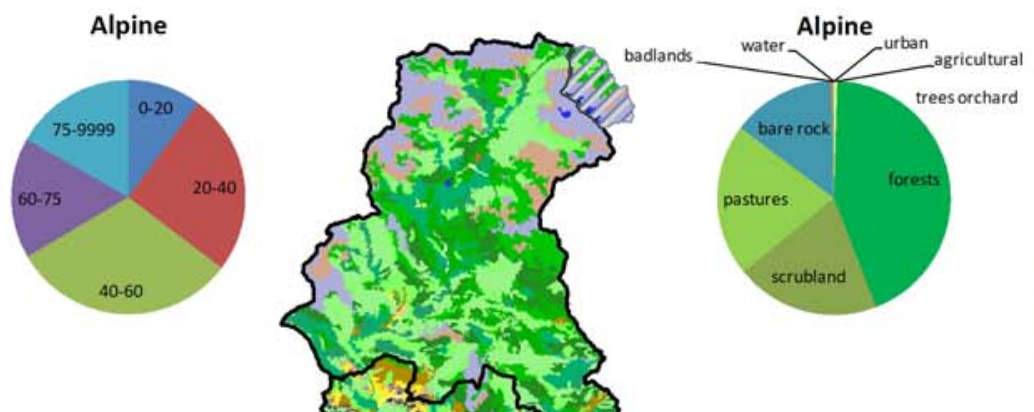

\section{Land uses/Land covers}

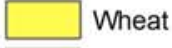

Barley

Vegetable orchard

Orchard

Range grasses

Alpine pasture
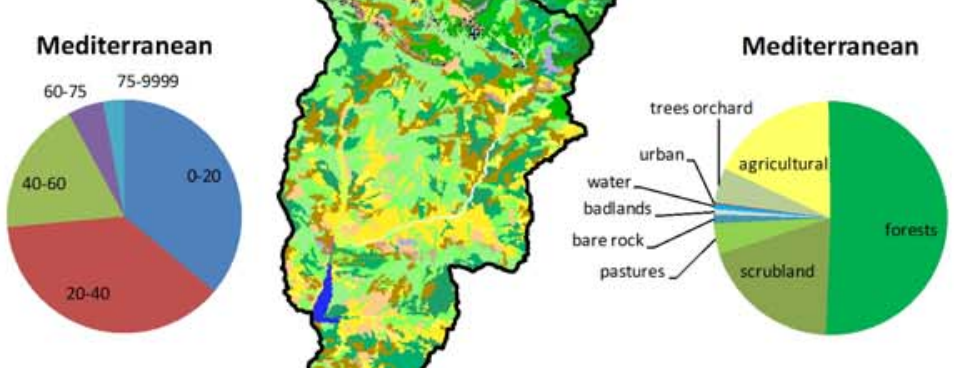

Dense scrubland

Open scrubland

Garrigas

Deciduous forest

Evergreen forest

Mixed forest

Pine

Badland

Rock outcropt

Urban

c)

Rock outcropt
Urban
Water

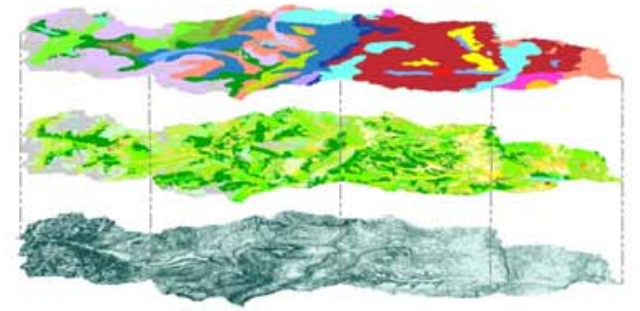

Soil map

Land use/Land cover map

Slope map

Fig. 1.- a) Location of the Barasona catchment in Europe and the distribution of the hydrological network and the weather stations used in the SWAT model; b) distribution of the slope ranges and the land uses in the northern and southern parts of the catchment; and c) spatial sources overlapped to discretise into HRUs in SWAT model. 
The climate is defined as mountain type, wet and cold with both Atlantic and Mediterranean influences. Temperature and precipitation gradients are observed for both north-south and west-east regions according to the relief, along with the influences of the Atlantic Ocean and Mediterranean Sea. The average annual precipitation and temperature range from more than $2000 \mathrm{~mm}$ and $4{ }^{\circ} \mathrm{C}$ in the headwaters, to less than $500 \mathrm{~mm}$ and $12{ }^{\circ} \mathrm{C}$ at the Barasona Reservoir.

The hydrologic regime of the study area is transitional nival-pluvial characterized by two maxima; the spring period (April-June), due to snowmelt and the late autumn (OctoberNovember) due to precipitation (García-Ruiz et al., 2001). Snow covers the catchment above 1700 m a.s.l. from mid November to May. High slopes and the presence of deep and narrow gorges favour rapid runoff and large floods. The catchment is drained by the Ésera River and its main tributary, the Isábena River. Part of the Ésera headwater $\left(28.9 \mathrm{~km}^{2}\right)$ was discounted as an effective drainage area because it drains through a subterranean route through the Jueu Karst System to the Garona River, on the Atlantic northern side of the Pyrenees. This represents an average discharge loss of about $3 \mathrm{~m}^{3} \mathrm{~s}^{-1}$ from the Ésera River (López-Moreno et al., 2002). Small headwater reservoirs (such as the Linsoles and Paso Nuevo reservoirs which are both of $3 \mathrm{hm}^{3}$ ), canals and dams for hydropower purposes regulate the Ésera River, whereas the Isábena River is non-regulated.

The area is characterized by heterogeneous relief, vegetation and soils. The catchment altitudes comprise from $424 \mathrm{~m}$ a.s.l. at the catchment outlet (Barasona reservoir) to $3404 \mathrm{~m}$ a.s.l. (Aneto Peak) in the northern headwater of the catchment. The distribution of the altitudes and slope ranges decreases in value from the north to the south of the catchment.

In general, the soils are stony and alkaline, overlying fractured bedrock with textures from loam to sandy loam. Soils are mostly shallow $(<0.6 \mathrm{~m})$ and well drained with limited average water content and moderate to low structural stability. The predominant soil types (FAO 
2007; based on the Soil Map of Aragón, Machín, unpublished data, 2000) are Kastanozems (33\%) with substantial accumulations of organic matter and other poorly developed mineral soils with low organic matter content $(<2-3 \%)$, Regosols, Leptosols and Fluvisols. The latter three take up to $40 \%$ of the study area, while other soil types are scarcely represented.

Although the development of badlands on erodible materials is considered to be characteristic of arid regions, they also occur in mountainous areas with wetter climates and high intensity storm events, such as in the Southern Alps (e.g., Mathys et al., 2005) and the Pyrenees (e.g., Clotet et al., 1988; Gallart et al., 2002; Nadal-Romero et al., 2006). Despite the fact that the badlands on the Eocene marls represent less than $1 \%$ of the total catchment area, they constitute the most important sediment source in the catchment (e.g. Alatorre et al., 2010; López-Tarazón et al. 2012, see location in Fig. 1b).

Based on the land use map digitalized by the Corine Land Cover European project (CLC2000) and modified to include the badland extension, the area comprises of forests (47\%), scrublands (20\%), grasslands (12\%), agricultural uses (12\%), bare rocks (7\%), badlands (0.4\%), water bodies ( $<1 \%)$, and infrastructure and built-up areas $(<1 \%)$ (Table 1$)$.

In addition to the climatic and physiographic gradients, differences in the presence and distribution of the land uses, land covers and soil types have permitted the division of the catchment into two parts of a similar extension: the alpine northern part $\left(686 \mathrm{~km}^{2}\right)$ and the Mediterranean southern part $\left(793 \mathrm{~km}^{2}\right)$ (Fig. 1b). Atlantic and continental Mediterranean climatic influences prevail in the northern and southern parts, respectively. More than half of the surface of the northern part has more than $40 \%$ slope whereas only $24 \%$ of the southern part presents this slope range. Although both parts present similar percentage distribution for some land uses and land covers, bare rock and grassland dominate the northern part while cultivated land extends more over the more gentle southern area. Differences in soil types 
between parts of the catchment are also evident as more developed soils are present in the more gentle southern part and young and mineral soils prevail in the abrupt northern part.

Table 1.- Characteristics and distribution of the land uses in the Barasona catchment.

\begin{tabular}{|c|c|c|c|c|c|c|}
\hline Group & Land use & Description & $\begin{array}{l}\text { Area } \\
\left(\mathrm{km}^{2}\right)\end{array}$ & $\begin{array}{l}\% \text { of the } \\
\text { catchment }\end{array}$ & $\begin{array}{l}\text { Average } \\
\text { slope } \\
\text { (\%) }\end{array}$ & $\begin{array}{l}\text { Soil type } \\
\text { (\%) }\end{array}$ \\
\hline \multirow[t]{5}{*}{ Agricultural } & WHEA & Wheat & 25.05 & 1.7 & 36 & KSc (63) \\
\hline & BARL & Barley & 108.13 & 7.3 & 33 & KSc (52) \\
\hline & VEGE & Vegetable orchard & 9.76 & 0.7 & 27 & FLc (45) \\
\hline & ORCD & Orchard & & & & \\
\hline & & $\begin{array}{l}\text { (Olive, almond and } \\
\text { fruit orchards) }\end{array}$ & 38.92 & 2.6 & 33 & KSc (54) \\
\hline \multirow[t]{3}{*}{ Pastures } & RNGR & Range grasses & 68.65 & 4.6 & 43 & LPk2 (39) \\
\hline & PAST & & & & & KScLPkKSh2 \\
\hline & & Alpine pastures & 110.37 & 7.5 & 46 & (38) \\
\hline \multirow[t]{4}{*}{ Scrublands } & DNSC & Dense scrubland & 88.48 & 6.0 & 50 & PHh (19) \\
\hline & OPSC & & & & & KScLPkKSh2 \\
\hline & & Open Scrubland & 75.31 & 5.1 & 48 & (55) \\
\hline & GARR & Garrigues & 125.73 & 8.5 & 45 & KSc (47) \\
\hline \multirow[t]{4}{*}{ Forests } & FRSD & Deciduous Forest & 147.61 & 10.0 & 47 & KSc (23) \\
\hline & FRSE & Evergreen Forest & 192.85 & 13.0 & 47 & KSc (34) \\
\hline & FRSM & Mixed Forest & 77.69 & 5.2 & 46 & KSc (37) \\
\hline & PINE & Coniferous forest & 282.75 & 19.1 & 48 & KSc (23) \\
\hline \multirow[t]{2}{*}{ Badlands } & BADL & Bare soil (Badlands) & 5.98 & 0.4 & 48 & None \\
\hline & Others & $\begin{array}{l}\text { Bare rock, water, } \\
\text { urban }\end{array}$ & 122.64 & 8.3 & 37 & None \\
\hline
\end{tabular}

\subsection{Modelling approach}

\subsubsection{SWAT model}

SWAT, the Soil and Water Assessment Tool, is a physically-based, semi-distributed, agrohydrological model that operates on a daily time step (as a minimum) at catchment scale. SWAT is designed to predict the impact of management on water, sediment and agricultural chemical yields in ungauged catchments (Arnold et al. 1998). This model was selected for this study as it is capable of continuous simulation for dissolved and particulate elements in large complex catchments with varying weather, soils and management conditions over long time periods. Major model components include weather, hydrology, soil temperature and properties, plant growth, nutrients, pesticides, bacteria and pathogens and land management. 
Theory and details of different processes integrated with the SWAT model are available online in SWAT, 2011 documentation (http://swatmodel.tamu.edu/).

SWAT can analyse small or large catchments by discretising into sub-basins, which are then further subdivided into Hydrological Response Units (HRUs) by distinctive combinations of categorized land uses, soil types, and slope. The model simulates water balance inside each HRU, taking into account rainfall, evapotranspiration, surface and subsurface runoffs and deep aquifer recharge. Vegetation growth is modelled by taking into account plant phenological development, leaf area development, light interception and conversion into biomass. The sediment from sheet erosion for each HRU is calculated using the Modified Universal Soil Loss Equation (MUSLE; Williams, 1995).

Therefore, erosion and sediment delivery are estimated as a function of peak runoff rate and volume and physical factors such as soil erodibility, slope steepness and length, cover factor $\left(C_{U S L E}\right)$, and supporting practise factor, which corresponds to flow volume within the channel on a given day. The cover and management factor $\left(C_{U S L E}\right)$ is recalculated everyday that runoff occurs and it is a function of above-ground biomass, residue on the soil surface, and the minimum C factor for the plant (Neitsch et al. 2011). Plant production is very dependent on temperature; therefore, temperature affects the erosion process by changing the percentage leaf area index covered by vegetation.

\subsubsection{The Barasona catchment model setup and erosion assessment}

The study area was discretised into HRUs using: (i) a derived 5 ranges slope map based on a digital elevation model (DEM; 25 x 25 m) obtained from the National Geographic Institute (IGN, 2011); (ii) a land use map that was extracted, edited and resampled from the European Project Corine Land Cover map (CLC2000); and (iii) the Digital Soil Map of Aragón at a scale of 1:500,000 (Soil Map of Aragón, Machín, unpublished data, 2000). The overlapping 
of these spatial sources (Fig. 1c) resulted in 5399 HRUs (see details in Palazón and Navas, 2014).

Climate inputs of daily minimum and maximum temperatures and rainfall data in this SWAT project were based on measured historic data within or close to the region. Thus, rainfall records from four stations were selected from a revised database (1955-2006; VicenteSerrano et al. 2009), and daily temperature records from five stations were obtained from the State Meteorological Agency (AEMET, Fig. 1a). To account for temperature and precipitation gradients according to the relief, ten homogeneous elevation bands and their lapse rates in height were defined in each subcatchment. The temperature lapse rate in height (TLAPS: temperature lapse rate in SWAT) was set to $-5^{\circ} \mathrm{C} \mathrm{km}^{-1}$, which is in close agreement with the estimated values for the Pyrenean region. The precipitation lapse rate in height (PLAPS: precipitation lapse rate in SWAT) is defined by subcatchment to account with the described rates of precipitation in the catchment. It is widely documented that the precipitation gradient per year decreases from $1000 \mathrm{~mm} \mathrm{~km}^{-1}$ to almost half above $2000 \mathrm{~m}$ a.s.l. in the study region (Rijckborst 1967; García-Ruiz et al. 2001). The PLAPS for the subcatchments range from 550 to $1000 \mathrm{~mm} \mathrm{~km}^{-1}$.

This work is based on a previous calibration of the SWAT model for the Barasona catchment (Palazón and Navas, 2014) which performed Nash-Sutcliffe efficiency coefficients (Nash and Sutcliffe, 1970) greater than 0.7 and solved important challenges of the catchment for model simulation when applied to the catchment headwater (Palazón and Navas, 2013). The snowfall-snowmelt processes, the dammed characteristics of a river and the headwater streamflow losses by a karstic system were the most important calibrated issues, more details in Palazón and Navas (2013 and 2014). The sediment supplies to the reservoir compared well with other studies in the region (e.g.: Alatorre et al. 2010; López-Tarazón et al. 2012). This comprehensive calibration for hydrology and sediment supplies to the Barasona reservoir of 
the SWAT model served as a base to assess the differences in sediment production from the land uses of the catchment under different climatic conditions. Therefore, data from two years from the simulation in the previous study (Palazón and Navas 2014) are selected and used for this study as they have a large contrast in precipitation (2003 and 2005, Fig. 2). In addition to differences in precipitation, the average annual precipitation of $1063 \mathrm{~mm}$ for the reference period 1961-1990 (World Meteorological Organization) for the Sesué weather station (Fig.1a) has defined the years 2003 and 2005, as wet and dry years, respectively. The simulated sediment production from the 5399 HRUs is averaged by land use/land cover (Table 1) to provide the specific sediment yield from the land uses $\left(\mathrm{SSY}_{\mathrm{LU}}, \mathrm{t} \mathrm{ha}^{-1} \mathrm{year}^{-1}\right)$. Those are assessed and compared between climatic conditions of contrasted precipitation amounts and temperature rates of increase. The $\mathrm{SSY}_{\mathrm{LU}}$ for the difference in precipitations is assessed annually and seasonally to compare yields between years and to assess the differences in the seasons. Furthermore, the $\mathrm{SSY}_{\mathrm{LU}}$ for both compared climatic conditions is assessed for the land uses present in the northern alpine and southern Mediterranean parts of the catchment (Fig.1b). Therefore, to compare the sediment production under different precipitations, the SSY $_{\mathrm{LU}}$ is compared annually and seasonally for the whole and the parts of the catchment. To assess how an increase of temperature could affect the sediment production, a scenario with a uniform increase of temperature of $2^{\circ} \mathrm{C}\left(2^{\circ} \mathrm{S}\right)$ was simulated to compare the obtained $\mathrm{SSY}_{\mathrm{LU}}$ with the scenario with the observed data (OS). The increase of temperature was selected as it is in range with the expected increase trend in temperature in the Spanish Pyrenean range (López-Moreno et al. 2008; Ribalaygua et al. 2013). Seasonal temperature variations were not taken into account as its values are not certain. The SSY $\mathrm{LU}_{\mathrm{C}}$ comparison between the OS and the $2^{\circ} \mathrm{S}$ is assessed annually for the whole and the parts of the catchment. As different magnitudes of sediment yields by land use could be expected, the differences in SSY $\mathrm{LU}_{\mathrm{LU}}$ are assessed by estimating the percentage change (PC, \%) in comparing the 2003 to the 2005 year 
for the precipitation assessment and between the OS and the $2^{\circ} \mathrm{S}$ scenarios for the temperature assessment. Moreover, as precipitation does not change equally between 2003 and 2005 for the different seasons, the PC relative to the percentage change between precipitations for each season (PS/PP) was assessed to show on absolute values how these differences in precipitation by season would affect the changes in sediment yield.

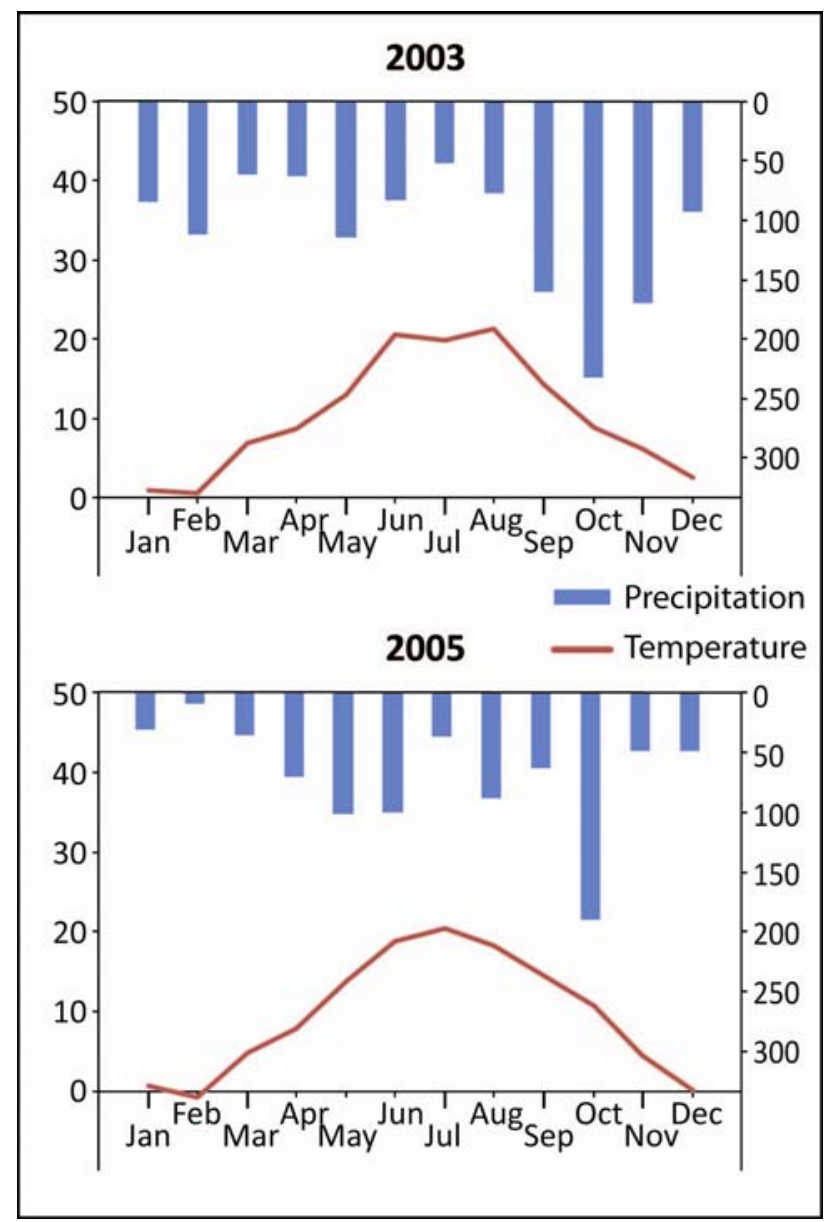

Fig. 2.- Climographs for the years 2003 and 2005.

\section{Results}

\subsection{The sediment production from the different land uses}

Large differences were observed in the $\mathrm{SSY}_{\mathrm{LU}}$ for the study years 2003 and 2005 (Table 2). Apart from badlands, the sediment productions from the groups of land uses were ordered as follows: agricultural uses (wheat, barley and vegetable orchard in Table 2) produced the highest sediment yields, followed by pastures (range grasses and alpine pastures) and 
scrublands (dense scrubland, open scrubland and garrigues) whereas the lowest sediment productions come from the forests (deciduous forest, evergreen forest, mixed forest and pine) and orchards (olive, almond and fruit orchards). The badlands with the highest $\mathrm{SSY}_{\mathrm{LU}}$ produced more than 2 orders of magnitude values from the other land uses and land covers.

For measured precipitations of 1383 and $871 \mathrm{~mm}$, and temperatures of 10 and $9^{\circ} \mathrm{C}$, in 2003 and 2005, respectively, the SSY $\mathrm{LU}_{\mathrm{U}}$ was 2 to 5 times greater in the wet year than in the dry year. Comparing 2003 and 2005 the PC in SSY $_{\mathrm{LU}}$ for each land use differed between groups of land uses (Table 2). Therefore, agricultural uses had the lowest PC of SSY $\mathrm{LU}_{\text {between years }}$ and badlands had intermediate PC values. The other land uses had similar high PC of SSY $\mathrm{LU}$ between years. From those, pastures and orchards had the highest PC, scrublands intermediate PC and the lowest PC were for forests.

Table 2.- Average specific sediment yield $\left(\mathrm{t} \mathrm{ha}^{-1} \mathrm{year}^{-1}\right)$ by land use for the study years and the percentage difference (PC; \%) between the wet year (2003) and the dry year (2005).

\begin{tabular}{|c|c|c|c|c|c|}
\hline Group & & Description & 2003 & 2005 & PC \\
\hline \multirow[t]{5}{*}{ Agricultural } & WHEA & Wheat & 2.182 & 1.039 & 52.4 \\
\hline & BARL & Barley & 1.538 & 0.782 & 49.2 \\
\hline & VEGE & Vegetable orchard & 0.497 & 0.318 & 36.1 \\
\hline & & $\begin{array}{l}\text { Orchard } \\
\text { (Olive, almond and }\end{array}$ & & & \\
\hline & ORCD & fruit orchards) & 0.027 & 0.005 & 80.2 \\
\hline \multirow[t]{2}{*}{ Pastures } & RNGR & Range grasses & 0.475 & 0.093 & 80.4 \\
\hline & PAST & Alpine pastures & 0.169 & 0.036 & 78.6 \\
\hline \multirow[t]{3}{*}{ Scrublands } & DNSC & Dense scrubland & 0.149 & 0.036 & 75.6 \\
\hline & OPSC & Open Scrubland & 0.141 & 0.036 & 74.7 \\
\hline & GARR & Garrigues & 0.032 & 0.006 & 80.9 \\
\hline \multirow[t]{4}{*}{ Forests } & FRSD & Deciduous forest & 0.120 & 0.026 & 78.2 \\
\hline & FRSE & Evergreen forest & 0.016 & 0.004 & 73.4 \\
\hline & FRSM & Mixed Forest & 0.023 & 0.008 & 64.5 \\
\hline & PINE & Coniferous forest & 0.018 & 0.005 & 73.5 \\
\hline Badlands & BADL & Bare soil (Badlands) & 135.836 & 41.942 & 69.1 \\
\hline
\end{tabular}

Apart from the spring precipitations, the seasonal distribution of the precipitations for the study years differed markedly but this was not the case for the seasonal distribution of the temperatures (Table 3). Seasonally, the sediment production pattern was similar to the annual pattern. For both years and all land uses, the $\mathrm{SSY}_{\mathrm{LU}}$ was higher in spring and autumn than in 
summer and winter (Fig. 3). The lowest $\mathrm{SSY}_{\mathrm{LU}}$ for most land uses (except barley and vegetable orchard in summer) was recorded in the winter of 2005. Apart from this driest winter in 2005, summer was the season when the land uses yielded the lowest $\mathrm{SSY}_{\mathrm{LU}}$ for both years. Apart from vegetable orchards, pastures, deciduous forest and open scrubland which yielded greatest $\mathrm{SSY}_{\mathrm{LU}}$ in spring 2003, the other land uses performed their highest $\mathrm{SSY}_{\mathrm{LU}}$ in the wettest season which was autumn 2003. Differences in sediment productions between years were highest in winter and lowest in spring and autumn. The agricultural uses (wheat, barley and vegetable orchards), mixed forests and pine had their least PC in spring, whereas for the other land uses it was in autumn. Although both years had very similar precipitations in spring, this was the season with the highest variation in the PC between the years (from 2 to 87\%), amongst land-uses. The lowest PC corresponded to the agricultural uses with less than $20 \%$ for the wheat and less than $4 \%$ for the barley and vegetable orchards. Pastures, vegetable orchards, deciduous forest, garrigues and open scrubland had a PC greater than 80\%. All seasons, forests, scrublands, pastures and orchards had a higher PC between years than agricultural crops. Apart from spring which also showed the highest variation in the PS/PP in Fig. 3, the other seasons have very similar values of PS/PP for the land uses. Therefore, apart from the spring, the PC from the land uses decreased slightly more than decreased precipitations between 2003 and 2005.

Table 3.- Seasonal precipitation (mm) and temperature $\left({ }^{\circ} \mathrm{C}\right)$ for the selected wet (2003) and dry (2005) years.

\begin{tabular}{rrrrrrrrr} 
& \multicolumn{2}{c}{ Winter } & \multicolumn{2}{c}{ Spring } & \multicolumn{2}{c}{ Summer } & \multicolumn{2}{c}{ Autumn } \\
& $\mathrm{mm}$ & ${ }^{\circ} \mathrm{C}$ & $\mathrm{mm}$ & ${ }^{\circ} \mathrm{C}$ & $\mathrm{mm}$ & ${ }^{\circ} \mathrm{C}$ & $\mathrm{mm}$ & \multicolumn{1}{c}{${ }^{\circ} \mathrm{C}$} \\
\hline 2003 & 273 & 3 & 277 & 14 & 309 & 18 & 524 & 6 \\
2005 & 80 & 2 & 288 & 13 & 199 & 18 & 305 & 5 \\
\hline
\end{tabular}




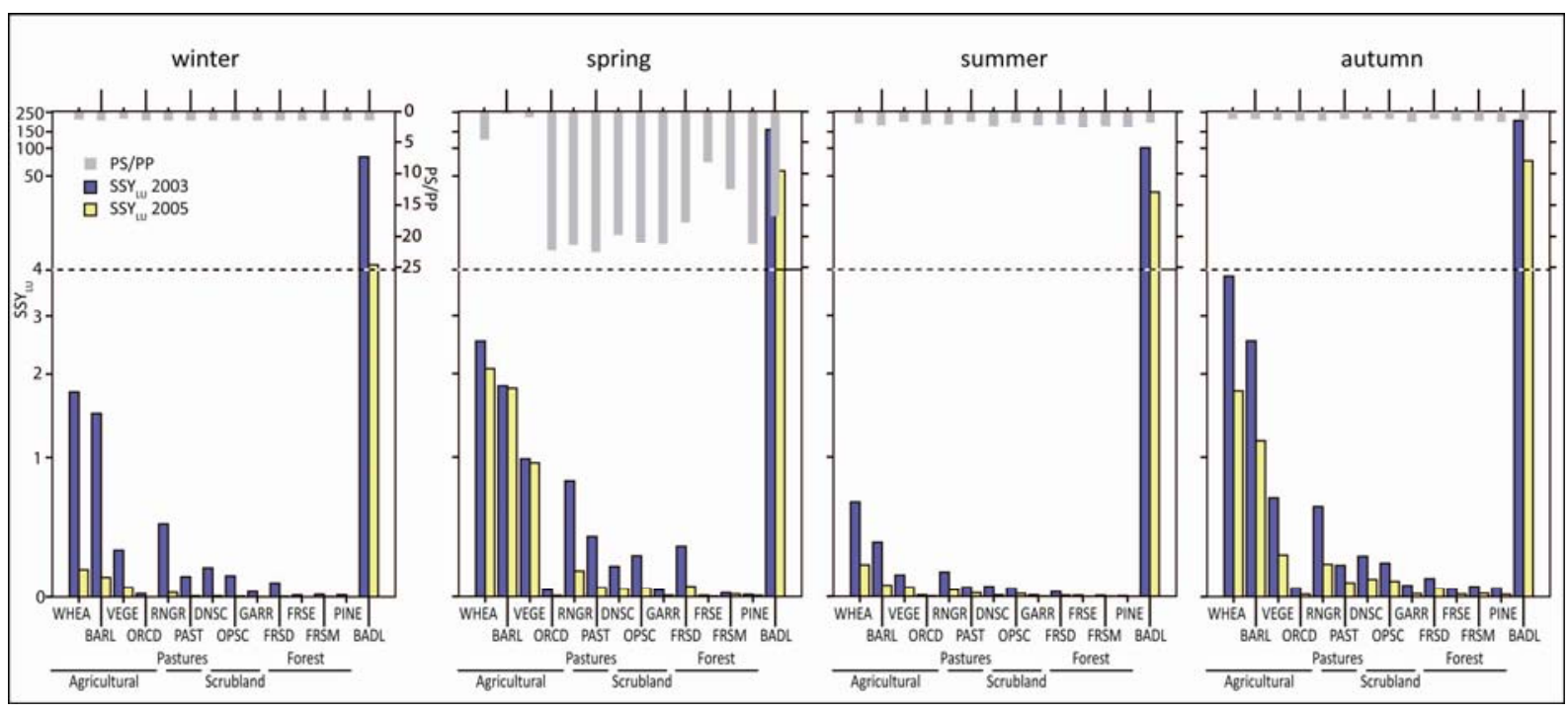

Fig. 3.- Seasonal specific sediment yield from the land uses $\left(\mathrm{SSY}_{\mathrm{LU}}\right.$; $\mathrm{t} \mathrm{ha}^{-1}$ year $\left.^{-1}\right)$ and inverted in the secondary axis as their percentage change relative to differences in precipitation for each season (PS/PP) for the catchment.

\subsection{Sediment productions in the northern and southern parts of the catchment}

The characteristics of the model outputs make it possible to divide the catchment into two parts to assess PC in sediment productions from the land uses and climate (temperature and precipitation) existing between the northern and southern parts of the catchment (Tables 4 and 5). The annual and seasonal distributions of the precipitation for the two parts of the catchment were clearly different and the temperature was in average $3^{\circ} \mathrm{C}$ lower in the northern part than in the southern part of the catchment (Table 4). The annual patterns of the SSY $_{\mathrm{LU}}$ for the northern part and the southern part were similar to that of the whole catchment with higher sediment yields in the northern part than in the southern part for both years (Table 5). Apart from the barley crops and most forests (evergreen, mixed and pine), PC between years was higher in the northern part than in the southern part. In contrast, badlands performed very similarly on PC between years.

Table 4.- Annual and seasonal precipitations $(\mathrm{mm})$ and temperature $\left({ }^{\circ} \mathrm{C}\right)$ for the northern and southern parts of the catchment.

\begin{tabular}{rrrrrrrrrrrr} 
& & \multicolumn{2}{c}{ Annual } & \multicolumn{2}{c}{ Winter } & \multicolumn{2}{c}{ Spring } & \multicolumn{2}{c}{ Summer } & \multicolumn{2}{c}{ Autumn } \\
& & \multicolumn{1}{c}{$\mathrm{mm}$} & \multicolumn{1}{c}{$\mathrm{C}$} & $\mathrm{mm}$ & ${ }^{\circ} \mathrm{C}$ & $\mathrm{mm}$ & ${ }^{\circ} \mathrm{C}$ & $\mathrm{mm}$ & ${ }^{\circ} \mathrm{C}$ & $\mathrm{mm}$ & ${ }^{\circ} \mathrm{C}$ \\
\hline Northern & 2003 & 1707 & 8 & 371 & 1 & 343 & 12 & 374 & 16 & 620 & 4 \\
& 2005 & 1127 & 8 & 132 & 0 & 376 & 12 & 241 & 16 & 378 & 3 \\
Southern & 2003 & 994 & 12 & 170 & 5 & 190 & 16 & 236 & 20 & 398 & 7 \\
& 2005 & 597 & 11 & 31 & 3 & 189 & 15 & 149 & 19 & 228 & 7 \\
\hline
\end{tabular}


Table 5.- Average specific sediment yield $\left(\mathrm{SSY}_{\mathrm{LU}}\right.$; $\left.\mathrm{t} \mathrm{ha}^{-1} \mathrm{year}^{-1}\right)$ by land use for the alpine northern part and the Mediterranean southern part of the catchment and the percentage difference (PC; \%) between the wet year (2003) and the dry year (2005).

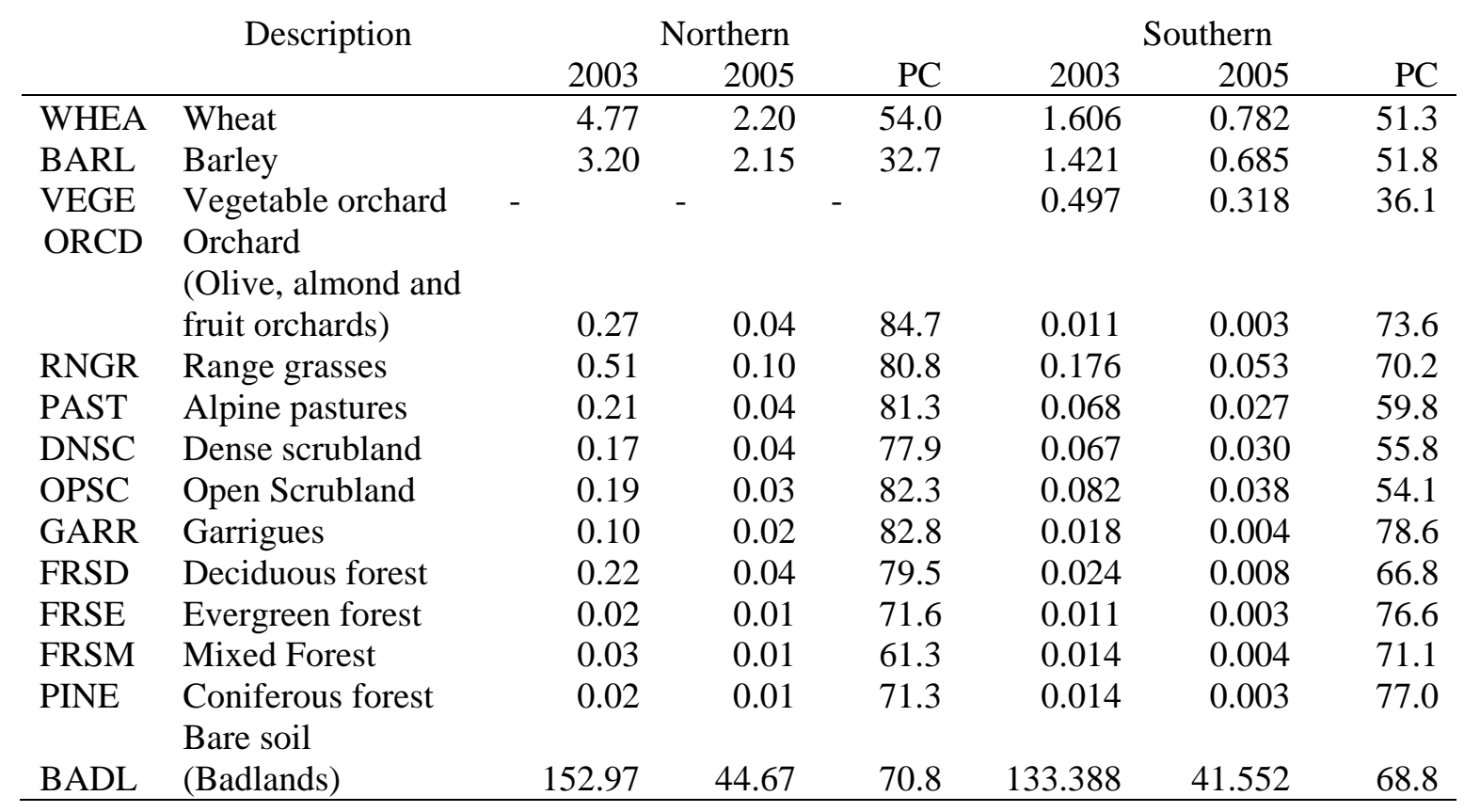

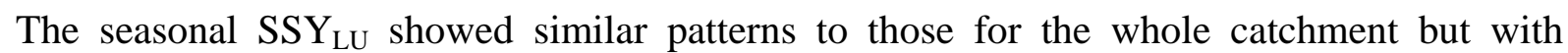
differences in the amount of $\mathrm{SSY}_{\mathrm{LU}}$ (Fig. 4). For both parts of the catchment the highest $\mathrm{SSY}_{\mathrm{LU}}$ differences between years occurred in winter with the greatest PC found in the southern part (Fig. 4). In the northern part most land uses performed the lowest PC in autumn whereas for the cereal crops, mixed forest and pine that were in spring. Apart from the range grasses and orchards, the lowest PC in the southern part was in spring with slight increases in SSY $_{\mathrm{LU}}$ from the cereal crops in 2005. Although for both parts of the catchment, the lowest SSY $_{\mathrm{LU}}$ in 2003 (except for the badlands of the southern part) was in summer, the sediment productions in 2005 were in general lower in winter than in summer. As for the whole catchment spring provided the highest variation in the PS/PP in contrast to the other seasons which showed similar values. 


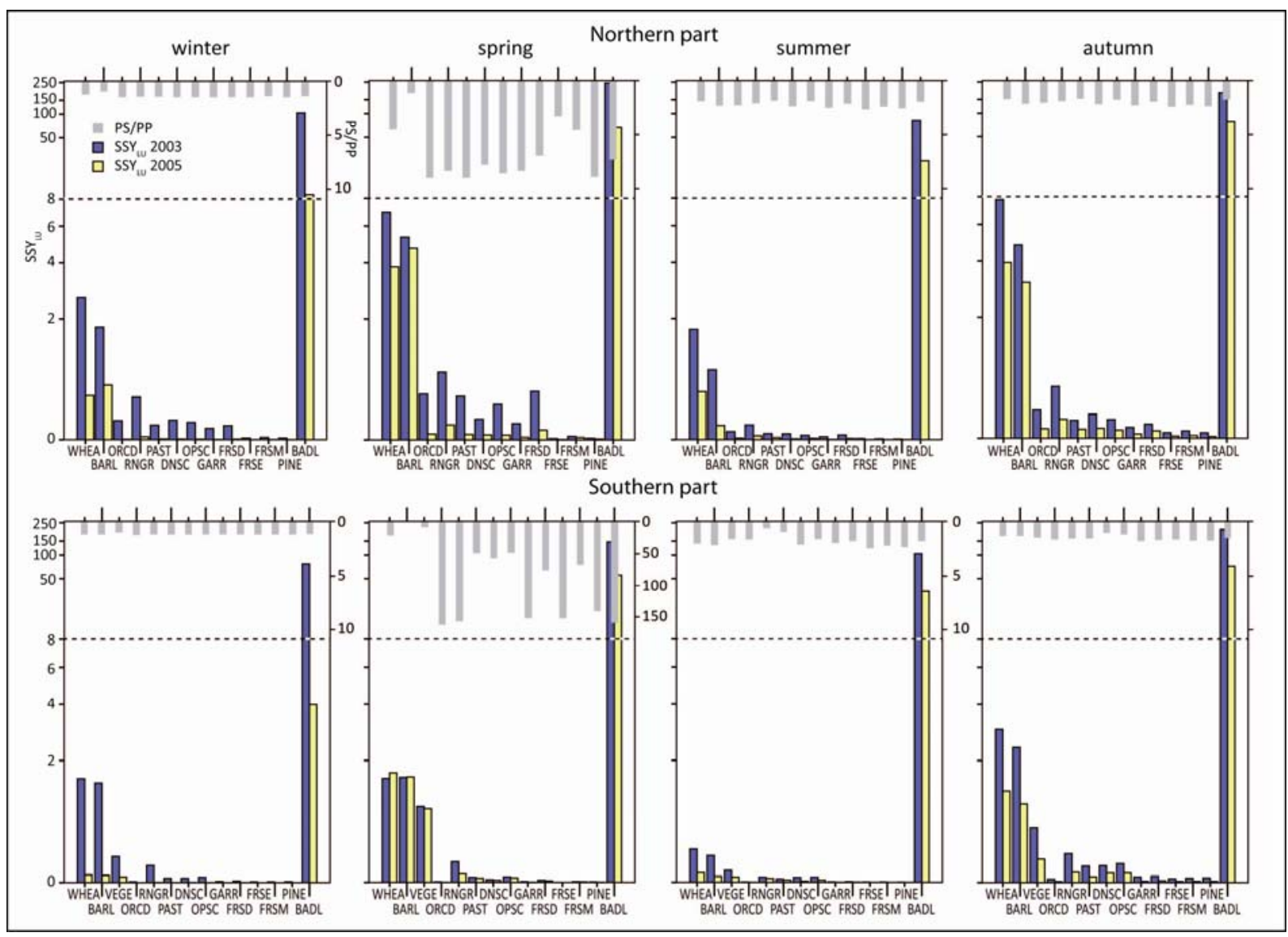

Fig. 4.- Seasonal specific sediment yield from the land uses (SSY $\mathrm{LU}_{\mathrm{U}}$; $\mathrm{ha}^{-1} \mathrm{year}^{-1}$ ) and inverted in the secondary axis as their percentage change relative to differences in precipitation for each season (PS/PP) for the northern and southern parts of the catchment for the study years.

\subsection{Scenario with an increase of $2^{\circ} \mathrm{C}$ temperature}

Comparing the simulated data of the scenario OS with the observed data with that of an increase of $2^{\circ} \mathrm{C}$ temperature, the $2^{\circ} \mathrm{S}$ had a general decrease in sediment production and variations in the water balance of the catchment (Fig 5 and 6). In relation to the OS scenario the simulated $2^{\circ} \mathrm{S}$ resulted in changes in the water balance of the catchment with evapotranspiration, water total yield and runoff increases together with decreases in the soil water content and the groundwater yields (Fig. 5). High significant relationships between the components of the SWAT water balance and the specific sediment yield for the catchment are found in Fig. 5; in spite of that, water yield, surface runoff and groundwater show slightly higher deviations in year 2003. Consequently, the specific sediment yield relationship between scenarios varied the most in 2003. Considering the monthly distribution of the 
components of the water balance, with an increase in temperature there were slight increases of the water amount for the first and ending months of the years and large decreases from April to July (Fig. 6). Concerning the evapotranspiration only slight differences between scenarios for both years were recorded. In contrast, lower snow accumulation occurred from September to May for the $2^{\circ} \mathrm{S}$. In relation to the average leaf area index, for the $2^{\circ} \mathrm{S}$ it was greater and advanced until June and lower for the second part of both years. The sediment production shared its highest differences in May and October with decreases which were more pronounced in the wet year.

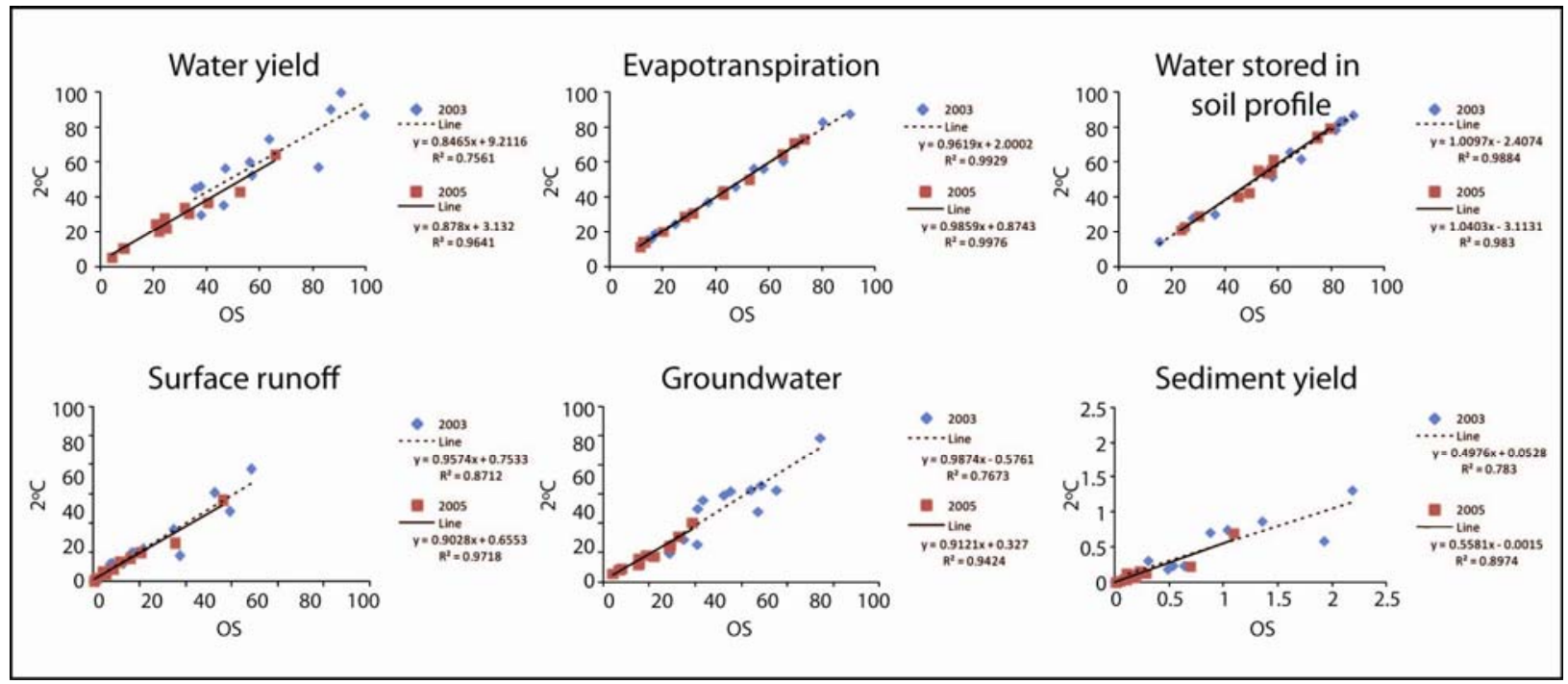

Fig. 5.- Water balance components and sediment yield relationships between the scenario with the observed data (OS) and the scenario with the temperature increase $\left(2^{\circ} \mathrm{S}\right)$ for 2003 and 2005 in the catchment.

Contrasted $\mathrm{SSY}_{\mathrm{LU}}$ was observed between the OS and $2^{\circ} \mathrm{S}$ scenarios for the assessed years (Fig. 7). The sediment production for the $2^{\circ} \mathrm{S}$ experienced a general decrease for the wet year but it did not for the dry one. For the dry 2005 the PC showed larger deviations than in 2003 with $\mathrm{SSY}_{\mathrm{LU}}$ increasing for most land uses, exceeding $10 \%$ in some cases. The garrigues had the greatest increase in the dry year but decreased in the wet year whereas the open scrubland showed important SSY $\mathrm{LU}_{\mathrm{U}}$ increases up to $80 \%$ for both years. Wheat also performed an which turned to an increase (up to 11\%) in 2005. Important SSY $\mathrm{LU}_{\mathrm{LU}}$ decreases for the deciduous forest and the dense scrubland were also observed, which for the latter was greater opposite in 
the dry year. In contrast the $\mathrm{SSY}_{\mathrm{LU}}$ from deciduous forest decreased greatly for both years

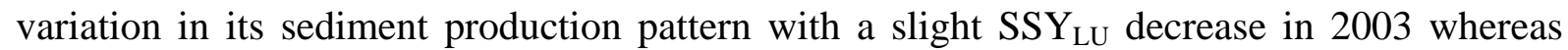
decreases from the dense scrubland had lower PC for the wet year than for the dry year.

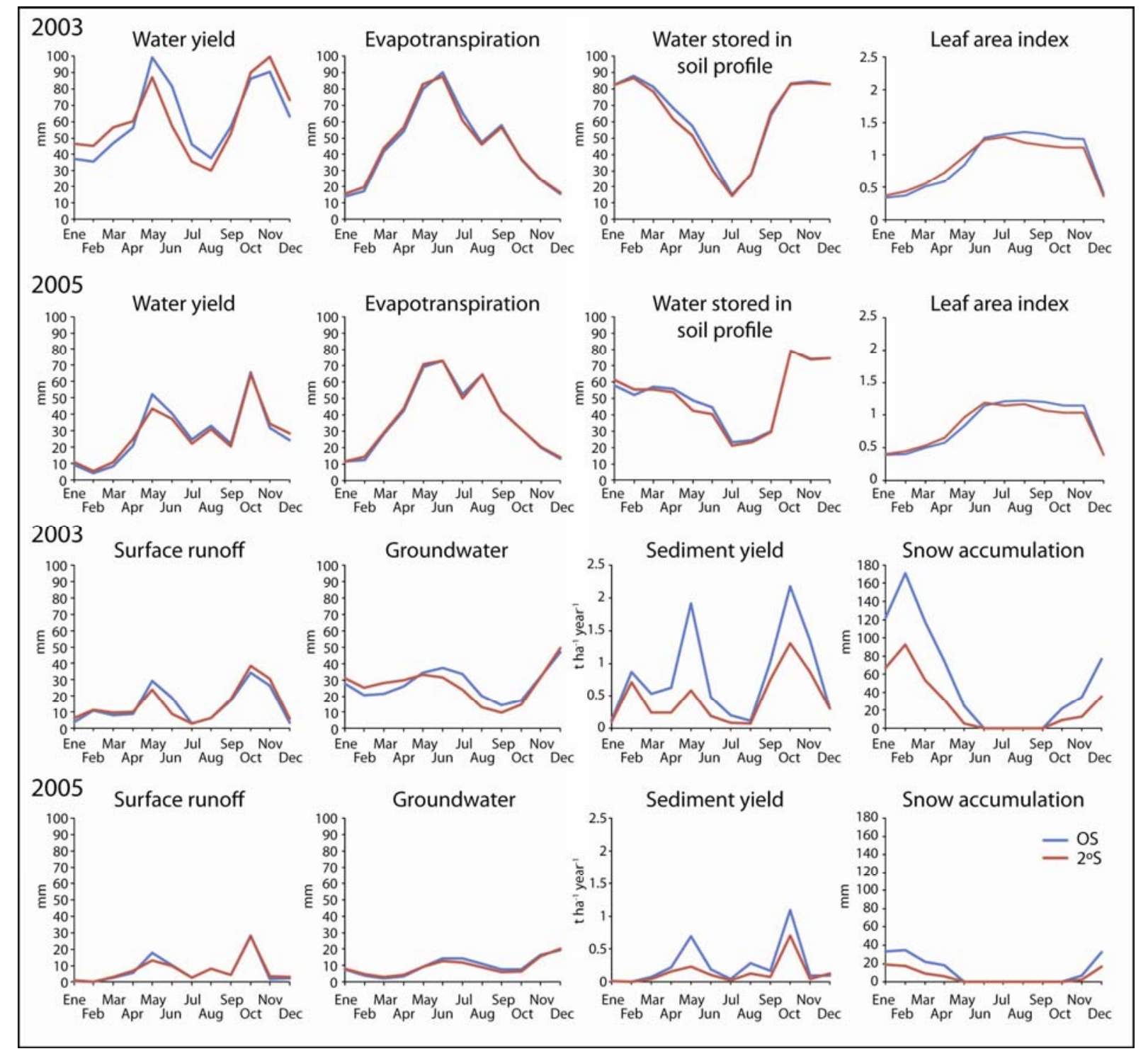

Fig. 6.- Monthly distribution values of the water balance components, the specific sediment yield, the leaf area index and the snow accumulation for the scenario with the observed data (OS) and the scenario with the temperature increase $\left(2^{\circ} \mathrm{S}\right)$ for 2003 and 2005 in the catchment. 


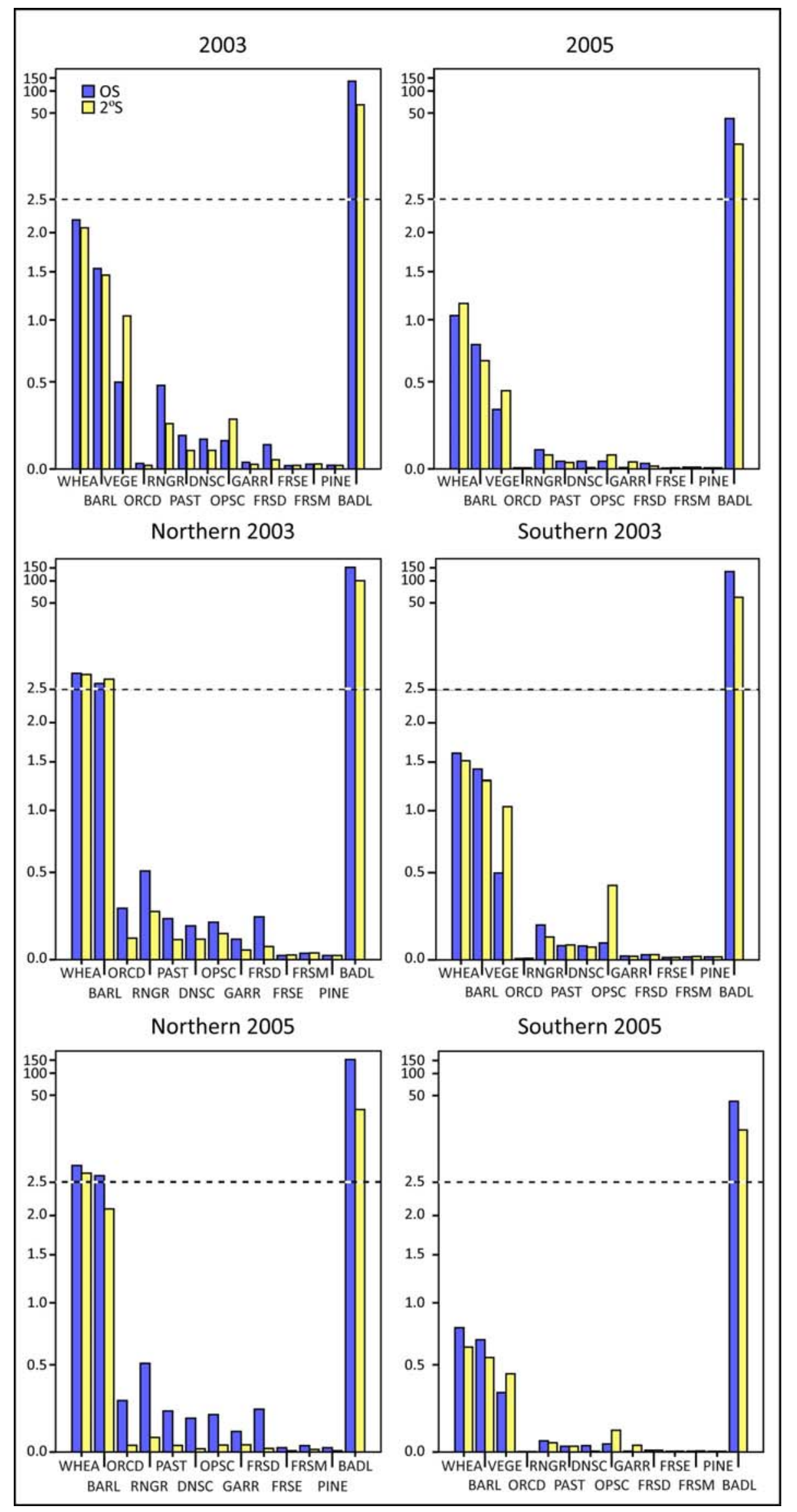

Fig. 7.- Specific sediment yield from the land uses (SSYLU; t ha-1 year-1) for the observed scenario (OS) and the scenario with the increase of $2^{\circ} \mathrm{C}\left(2^{\circ} \mathrm{S}\right)$ for the catchment and the northern and southern parts of the catchment. 
Different $\mathrm{SSY}_{\mathrm{LU}}$ was observed when increasing temperature by $2^{\circ} \mathrm{C}$ between the northern and southern parts of the catchment (Fig. 7). In general the differences between scenarios were greater; PC decreased for the northern part more than for the southern part, which also changed their pattern to increases in $\mathrm{SSY}_{\mathrm{LU}}$. In the wet year 2003 most $\mathrm{SSY}_{\mathrm{LU}}$ had a decreased pattern in the northern part, but this turned to increases in $\mathrm{SSY}_{\mathrm{LU}}$ in the southern part. The greatest change was for the open scrubland, which yielded intermediate PC decreases in the northern part but significant PC increases in the southern part. The pastures and the deciduous forest changed from large PC decreases to slight increases $(<5 \%)$. In contrast, the barley turned from a PC increase of up to $18 \%$ in the northern part to lower PC decreases in the southern part. The rest of the land uses did not change the SSY $\mathrm{Lu}_{\mathrm{L}}$ pattern between the catchment parts. Therefore, the garrigues and dense scrubland recorded greater PC decreases in the northern part than in the southern part. In contrast, the evergreen forest showed a greater SSY $\mathrm{LU}_{\mathrm{U}}$ increment in the southern part than in the northern. The wheat was the only land use that yielded similar $\mathrm{SSY}_{\mathrm{LU}}$ decreases in both parts of the catchment.

In the dry year 2005 less land uses changed their sediment production pattern between the catchment parts. Amongst those, the greatest differences in $\mathrm{SSY}_{\mathrm{LU}}$ were produced by the garrigues followed by the open scrubland that showed large decreases in $\mathrm{SSY}_{\mathrm{LU}}$ in the northern part but turned to significant $\mathrm{SSY}_{\mathrm{LU}}$ increases in the southern part. Excluding the pine, the forests also changed from important $\mathrm{SSY}_{\mathrm{LU}}$ decreases in the northern part to increases from low to intermediate values in the southern part. In contrast, the dense scrubland had important SSY $_{\mathrm{LU}}$ decreases in both catchment parts. The rest of the land uses also showed $\mathrm{SSY}_{\mathrm{LU}}$ decreases in both parts but with PC greater in the northern part than in the southern. The pastures and the range grasses had large PC decreases followed by the pine in the northern part but these had the lowest PC decreases in the southern part. 


\section{Discussion}

Simulated sediment productions from the assessed land uses and covers were in agreement with values from the literature (e.g. Alatorre et al. 2010; López-Vicente et al. 2013). Differences between sediment productions were mostly related to their vegetation covers and phenological development during the year which affected the protection and retention of soils facing erosion. As the annual development of the vegetation cover in agricultural lands differed from the rest of land uses, the agricultural uses performed different sediment production patterns yielding greater $\mathrm{SSY}_{\mathrm{LU}}$ and lowest PC between years and seasons.

Whereas vegetation covers influenced $\mathrm{SSY}_{\mathrm{LU}}$, both type and development, differences in precipitation between years and seasons were central in the sediment yields. The greater SSY $_{\mathrm{LU}}$ in 2003 as opposed to 2005 was due to the highest precipitation during 2003. Seasonal PC in sediment productions between years was also related to differences in precipitations as showed the lower values of PS/PP for most of the seasons, except spring. While in 2003, apart from autumn, the measured precipitations were very similar, the distribution of the precipitation in 2005 was more varied and these relations have influenced the seasonal SSY $_{\mathrm{LU}}$. The large difference in winter precipitations between simulated years resulted in the highest PC in $\mathrm{SSY}_{\mathrm{LU}}$ for all land uses and the lowest $\mathrm{SSY}_{\mathrm{LU}}$ from most land uses (except barley and vegetable orchard in summer) during the driest winter in 2005. In spite of the spring precipitations being similar in both years, the difference in precipitations of the preceding season might have contributed to differences in sediment production as only the agricultural uses (wheat, barley and vegetable orchards), mixed forests and pine performed their least PC in $\mathrm{SSY}_{\mathrm{LU}}$ between years. Furthermore, diversities in vegetation cover developments influenced by water availability also contributed to these differences as indicated on the variability in PS/PP for spring. Although the autumn precipitation in 2003 almost doubled that in 2005, it was the wettest season for both years and, therefore, most land 
uses recorded their greatest $\mathrm{SSY}_{\mathrm{LU}}$ and their least PD in $\mathrm{SSY}_{\mathrm{LU}}$ between years. The low SSY $_{\mathrm{LU}}$ in the summers of both years might be more related to the greatest development of the vegetation cover in this season which would limit the water content in the soil due to higher evapotranspiration. In turn, this lower water content in the soil during summer might have also an effect on runoff restriction by favouring infiltration.

The greater $\mathrm{SSY}_{\mathrm{LU}}$ in the northern part of the catchment is because the annual precipitation in the northern part almost doubled that in the southern part for both years; in spite of that, higher slope gradients in the northern part likely had an effect on the $\mathrm{SSY}_{\mathrm{LU}}$, as their values almost doubled for the successive 5 slope range groups. The different seasonal sediment productions are also related to the seasonal distribution of the precipitations and the slope range. As for the catchment, the highest PC and lowest PS/PP between years for both parts of the catchment occurred in winter, due to the greatest differences in precipitation between years. Whereas, for both parts of the catchment the precipitations for summer and autumn in 2003 were around one and a half times greater than in 2005. Lower PC for the southern part points to the importance of the lower slope gradients and also that lower precipitations limited the sediment production in the southern part. As no vegetation cover protects the badlands, their sediment productions were only related with the precipitations and the availability of material to be eroded. Badlands had very similar PC between years and catchment parts because they are concentrated in the intermediate part of the catchment and therefore they are not affected by the precipitation gradients as are the other land uses.

In relation to the OS scenario the simulated $2^{\circ} \mathrm{S}$ resulted in changes in the monthly distribution of the components of the water balance likely associated with changes in the distribution of snowfall-snowmelt processes and the different vegetation developments related with the increase of temperature in the catchment. Whereas variations for the first and ending months of the year could be only associated with decreases in the snow accumulation, the 
latter large decreases from April to July could be the result of the combined effect of the lower water apportions by the snowmelt and the greater consumption of water by the more developed vegetation decreasing the water stored in the soil profile and its related surface runoff. Concerning the evapotranspiration and its high dependency on the temperature only slight differences between scenarios for both years that were lower than expected were recorded. However, greater differences between scenarios could have been masked in the averaged catchment value. All these simulated changes for $2^{\circ} \mathrm{S}$ had an effect on the sediment production that shared a general trend to decrease for both study years, which was more pronounced in the wet year.

Comparatively, differences in $\mathrm{SSY}_{\mathrm{LU}}$ between the OS and $2^{\circ} \mathrm{S}$ scenarios were greater for the southern part and the whole catchment in 2005 and mostly related to its drier characteristics. In spite of the surface runoff increased in autumn the $\mathrm{SSY}_{\mathrm{LU}}$ decreased for $2^{\circ} \mathrm{S}$ indicating that changes in vegetation growth resulted in a greater protection of the soil against erosion (e.g. Pimentel 2006). The greater and advanced average leaf area index for the $2^{\circ} \mathrm{S}$ could limit the sediment production in the first part of the year. Furthermore, as the total biomass was greater for $2^{\circ} \mathrm{S}$ it could increase the protection of the soil surface and also counteract the decrease of the leaf area index for the second part of the year. The differences in sediment productions were related to each specific plant phenological development which was the function of the cover factor $\left(C_{U S L E}\right)$ included in the MUSLE that is based in the total biomass and the leaf area index developed. Therefore, different adaptation strategies by the vegetation types were performed for the increment of temperature (Nunes et al. 2008). In most cases with the increase of temperature, the increase in vegetation growth was relatively more significant than the increase in surface runoff, leading to a decrease in erosion. Conversely, some land uses developed insufficient or reduced vegetation cover, resulting in increased erosion. These results point to that most land uses have a good tolerance to temperature increases of $2^{\circ} \mathrm{C}$, and 
a detrimental effect from this temperature in other land uses. Amongst those, the $\mathrm{SSY}_{\mathrm{LU}}$ decreases from the dense scrubland and the deciduous forest were due to greater development of their vegetation covers for $2^{\circ} \mathrm{S}$ and conversely appeared for the open scrubland which had $\mathrm{SSY}_{\mathrm{LU}}$ increases. On the contrary, the important $\mathrm{SSY}_{\mathrm{LU}}$ increases only in the dry year for the garrigues and the wheat were related to a detrimental effect on their vegetation covers by the temperature increase and the water limitation. While the different vegetation adaptations with the increase of temperature affect the $\mathrm{SSY}_{\mathrm{LU}}$, differences in slope, temperature and precipitation between catchment parts also influenced the $\mathrm{SSY}_{\mathrm{LU}}$. In addition to differences in precipitation, the lower temperature in the northern part than in the southern part appeared to also benefit the development of the vegetation covers in relation to the increase of temperature because for the northern part the PD decreases were greater.

Differences in SSY $\mathrm{LU}_{\mathrm{U}}$ observed in the contrasted northern and southern parts enabled us to obtain more specific information about the $\mathrm{SSY}_{\mathrm{LU}}$ and the vegetation response to the temperature increase. Therefore, the opposite pattern in sediment production observed for the open scrubland between catchment parts for both years could be related to the difference in temperatures. Lower temperatures in the northern part smoothed the increase of the temperature favouring the open scrubland development but did not in the southern part. Similar to that but only for the dry year it was recorded for the garrigues suggesting that low precipitations were unfavourable for their development. Differences in the PD decreases between catchment parts related to different increases in the vegetation cover for the dense scrubland and the deciduous forest for the $2^{\circ} \mathrm{S}$ could be due to differences in precipitation. Therefore, the dense scrubland appears to benefit more from drier conditions but whereas, the deciduous forest with wetter conditions recorded the greatest PD decreases. There were similar occurrences with the cereal crops as they recorded greater PD decreases in the dry year. As expected erosion increased with precipitation increases and decreased for higher soil 
surface protection by vegetation which was in agreement with results of other climatic studies (e.g. Nearing et al. 2005).

Nunes et al. (2008) developed a climatic assessment for two Portuguese catchments by SWAT to obtain land use erosion rates by scenarios of variable precipitation, temperature and $\mathrm{CO}_{2}$ concentrations. Their results for similar increases of temperature compare well with the SSY $_{\mathrm{LU}}$ results obtained in this study. Whereas, differences in the water balance responding to climate change between studies could be due to the absence of snow in their catchments. Comparable results to sediment production from their Mediterranean shrubs were obtained for the equivalent dense scrubland in our study which also increased their vegetation cover facing erosion on warmer conditions. Decreases in vegetation growth for the wheat and the pine were less noticeable in our study leading to minor decreases and increases in $\mathrm{SSY}_{\mathrm{LU}}$ for the $2^{\circ} \mathrm{S}$ at catchment scale.

\section{Conclusions}

The present study reveals the potential of the SWAT model for assessing the specific sediment yield under different land uses in a large alpine-prealpine catchment for two distinctive precipitation years and allows the identification of changes in the production of sediments for a simulated temperature increase scenario. Furthermore, the division of the catchment into two parts permitted an investigation of the specific sediment yield from land uses in the well differentiated climatic parts of the catchment the northern alpine part and the Mediterranean southern part.

Great variability of sediment production was observed and, in general, it was related with the characteristics of the assessed land uses and covers. The temporal variability was closely related to precipitation. The assessment verified that the highest sediment source came from the badlands, followed by the agricultural uses. Differences in specific sediment yield 
identified in the northern and southern parts of the catchment were related with the predominant climatic characteristics in each part, and also with their slope ranges. A general decrease in sediment production and changes in the water balance of the catchment were simulated for a $2^{\circ} \mathrm{C}$ temperature increase scenario. Changes in the snowfall and snowmelt processes for this increase of temperature affected the water balance of the catchment and the sediment production. The increase in the leaf area index and biomass production with the temperature increase was also significant in determining the response to soil erosion, particularly when considering different vegetation types. The sediment yields from the dense scrubland and the deciduous forest profited from the temperature increase in contrast with the

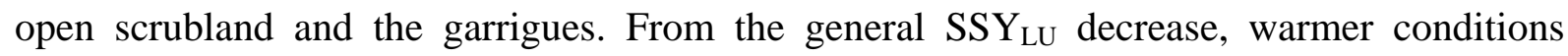
benefit more in the alpine northern part with greater sediment yield decreases than the Mediterranean southern part.

The SWAT model has proved useful as an initial approach to sediment yield assessment at a regional level and also for selecting priority areas where further analyses should be undertaken. The information obtained from this research will be of interest to assess the sediment produced under different land uses for differentiated climatic scenarios and areas in large alpine and pre-alpine catchments.

Acknowledgements: This research was financially supported by the project (CGL201452986-R).

\section{References:}

Alatorre, L.C., Beguería, S., García-Ruiz, J.M., 2010. Regional scale modeling of hillslope sediment delivery: A case study in the Barasona Reservoir watershed (Spain) using WATEM/SEDEM. J. Hydrol. 391,109-123. 
Arnold, J.G., Srinivasan, R., Muttiah, R.S., Williams, J.R., 1998. Large Area Hydrologic Modelling and Assessment Part I: Model Development. J. Am. Water Resour. As. 34(1),73-89.

Cerdà, A., Brazier, R., Nearing, M., de Vente, J., 2013. Scales and erosion. Catena 102, 1-2.

Clotet, N., Gallart, F., Balasch, C., 1988. Medium term erosion rates in a small scarcely vegetated catchment in the Pyrenees. Catena . 13, 37-47.

Corine Land Cover (2000) Available at http://www.eea.europa.eu/data-and-maps/data/corineland-cover-clc2000-100-m-version-12-2009

de Vente et al., 2008 de VenteJ.PoesenJ.VerstraetenG.Van RompaeyA.GoversG.Spatially distributed modelling of soil erosion and sediment yield at regional scales in SpainGlob. Planet. Chang.60 (3-4), 2008, 393-415.

Dessu, S.B., Melesse, A.M., Modelling the rainfall-runoff process of the Mara River basin using the Soil and Water Assessment Tool. Hydrol. Process. 26, 2012. 4038-4049.

Dessu, S.B., Melesse, A.M., Impact and uncertainties of climate change on the hydrology of the Mara River basin, Kenya/Tanzania. Hydrol. Process. 27, 2013, 2973-2986.

Dessu, S.B., Melesse, A.M., Bhat, M.G., McClain, M.E., Assessment of water resources availability and demand in the Mara River Basin. Catena, 115, 2014, 104-114.

FAO: IUSS Grupo de Trabajo WRB, Base Referencial Mundial del Recurso Suelo. Primera actualización 2007, In: Informes sobre Recursos Mundiales de Suelos No. 103, 2007, FAO; Roma.

Flynn, K.F., Van Liew, M.W., Evaluation of SWAT for sediment prediction in a mountainous snowmelt-dominated catchment. Trans. ASABE 54 (1), 2011, 113-122.

Foley, J.A., DeFries, R., Asner, G.P., Barford, C., Bonan, G., Carpenter, S.R., Chapin, F.S., Coe, M.T., Daily, G.C., Gibbs, H.K., Helkowski, J.H., Holloway, T., Howard, E.A., Kucharik, C.J., Monfreda, C., Patz, J.A., Prentice, I.C., Ramankutty, N., Snyder, P.K., Global consequences of land use. Science 309, 2005, 570-574.

Gallart, F., Llorens, P., Latron, J., Regüés, D., Hydrological processes and their seasonal controls in a small Mediterranean mountain catchment in the Pyrenees. Hydrol. Earth Syst. Sc. 6 (3), 2002, 527-537. 
García-Ruiz, J.M., Valero-Garcés, B.L., Historical geomorphic processes and human activities in the Central Spanish Pyrenees. Mt. Res. Dev. 18 (4), 1998, 309-320.

García-Ruiz, J.M., Beguería, S., López-Moreno, J.I., Lorente, A., Seeger, M., Los recursos hídricos superficiales del Pirineo aragonés y su evolución reciente, 2001. Geoforma Ediciones, Logroño.

García-Ruiz, J.M., López-Moreno, J.I., Vicente-Serrano, S.M., Lasanta-Martínez, T., Beguería, S., Mediterranean water resources in a global change scenario. Earth-Sci. Rev. 105, 2011, 121-139.

Gassman, P.W., Reyes, M.R., Green, C.H., Arnold, J.G., The Soil and Water Assessment Tool: Historical Development and Future Research Directions. Trans. ASABE 50(4), 2007, 1211-1250.

Kundzewicz, Z.W., Mata, L.J., Arnell, N.W., Döll, P., Kabat, P., Jiménez, B., Miller, K.A., Oki, T., Sen, Z., Shiklomanov, I.A., Freshwater resources and their management. In: Parry, M.L., Canziani, O.F., Palutikof, J.P., van der Linden, P.J., Hanson, C.E. (Eds.), Climate Change 2007: Impacts, Adaptation and Vulnerability. Contribution of Working Group II to the Fourth Assessment Report of the Intergovernmental Panel on Climate Change 2007, Cambridge University Press, Cambridge.

López-Moreno, J.I., Beguería, S., García-Ruiz, J.M., El régimen del río Ésera, Pirineo Aragonés, y su tendencia reciente. Bol. Glaciol. Aragon. 3, 2002, 131-162.

López-Moreno, J.I., Goyette, S., Beniston, M., Climate change prediction over complex areas: spatial variability of uncertainties and predictions over the Pyrenees from a set of regional climate models. Int. J. Climatol. 28, 2008. 1535-1550.

López-Tarazón, J.A., Batalla, R.J., Vericat, D., Francke, T., The sediment budget of a highly dynamic mesoscale catchment: The River Isábena. Geomorphology 138, 2012. 15-28.

López-Vicente, M., Poesen, J., Navas, A., Gaspar, L., Predicting runoff and sediment connectivity and soil erosion by water for different land use scenarios in the Spanish PrePyrenees. Catena 102, 2013. 62-73.

Luo, Y., Arnold, J., Allen, P., Chen, X., Baseflow simulation using SWAT model in an inland river basin in Tianshan Mountains, Northwest China. Hydrol. Earth Syst. Sc. 16, 2012. 1259-1267. 
Mathys, N., Klotz, S., Esteves, M., Descroix, L., Lapetite, J.M., Runoff and erosion in the Black Marls of the French Alps: observations and measurements at the plot scale. Catena 63, 2005. 261-281.

Molino, B., Viparelli, R., De Vincenzo, A., Effects of river network works and soil conservation measures on reservoir siltation. Int. J. Sediment. Res. 22, 2007, 273-281.

Morán-Tejeda, E., Zabalza, J., Rahman, K., Gago-Silva, A., López-Moreno, J.I., VicenteSerrano, S., Lehmann, A., Tague, C.L., Beniston, M., Hydrological impacts of climate and land-use changes in a mountain watershed: Uncertainty estimation based on model comparison. Ecohydrology 2015, http://dx.doi.org/10.1002/eco.1590

Morellón, M., Valero-Garcés, B.L., González-Sampériz, P., Vegas-Vilarrúbia, T., Rubio, E., Rieradevall, M., Delgado-Huertas, A., Mata, P., Romero, O., Engstrom, D.R., LópezVicente, M., Navas, A., Soto, J., Climate changes and human activities recorded in the sediments of Lake Estanya (NE Spain) during the Medieval Warm Period and Little Ice Age. J. Paleolimnol. 46 (3), 2011. 423-452.

Nash, J.E., Sutcliffe, J.V., River Flow Forecasting Through Conceptual Models: I. A Discussion of Principles. J. Hydrol. 10, 1970, 282-290.

Nadal-Romero, E., Regüés, D., Martí-Bono, C., Serrano-Muela, P., Dinámica estacional de los procesos de meteorización en cárcavas del Pirineo Central. Cuaternario y Geomorfología 20 (1-2), 2006, 61-77.

Navas, A., García-Ruiz, J.M., Machín, J., Lasanta, T., Walling, D., Quine, T., Valero, B., Soil erosion on dry farming land in two changing environments of the central Ebro Valley, Spain. In: Walling D.E and Probst J.L., (Eds) Human Impact on Erosion and Sedimentation. IAHS Publ. 245, 1997, 13 -20.

Navas, A., Valero, B., Machín, J., Walling, D., Los sedimentos del embalse de Joaquín Costa y la historia de su depósito. Limnetica 14, 1998, 93-112.

Navas, A., Valero-Garcés, B.L., Machín, J., An approach to integrated assessment of reservoir siltation: The Joaquín Costa reservoir as a case study. Hydrol. Earth Syst. Sc. 8 (6), 2004, 1193-1199.

Navas, A., Machín, J., Soto, J., Assessing soil erosion in a Pyrenean mountain catchment using GIS and fallout ${ }^{137}$ Cs. Agr. Ecosyst. Environ. 105, 2005, 493-506. 
Navas, A., Machín, J., Beguería, S., López-Vicente, M., Gaspar, L., Soil properties and physiographic factors controlling the natural vegetation re-growth in a disturbed catchment of the Central Spanish Pyrenees. Agroforest. Syst. 72 (3), 2008, 173-185.

Navas, A., Valero-Garcés, B.L., Gaspar, L., Machín, J., Reconstructing the history of sediment accumulation in the Yesa reservoir: an approach for management of mountain reservoirs. Lake Reserv. Manage. 25 (1), 2009, 15-27.

Navas, A., Valero-Garcés, B.L., Gaspar, L., Palazón, L., Machín, J., Radionuclides and stable elements in the sediments of the Yesa reservoir (Central Spanish Pyrenees). J. Soil. Sediment. 11 (6), 2011, 1082-1098.

Nearing, M.A., Jetten, V., Baffaut, C., Cerdan, O., Couturier, A., Hernandez, M., Le Bissonnais, Y., Nichols, M.H., Nunes, J.P., Renschler, C.S., Souchere, V., van Oost, K., Modeling response of soil erosion and runoff to changes in precipitation and cover. Catena 61 (2-3), 2005, 131-154.

Neitsch, S.L., Arnold, J.G., Kiniry, J.R., Williams, J.R., Soil and Water Assessment Tool Theoretical Documentation: Version 2009 2011, USDA, Soil and Water Research Laboratory/Blackland Research Center, Texas.

Nunes, J.P., Nearing, M.A., Modelling impacts of climatic change. In: Morgan, R.P.C., Nearing, M.A. (Eds.), Handbook of Erosion Modelling, 2011, Wiley-Blackwell, Oxford.

Nunes, J.P., Seixas, J., Pacheco, N.R., Vulnerability of water resources, vegetation productivity and soil erosion to climate change in Mediterranean watersheds. Hydrol. Process. 22 (16), 2008, 3115-3134.

Palazón, L., Navas, A., Sediment production of an alpine catchment with SWAT. Z. Geomorphol. 57 (2), 2013, 069-085.

Palazón, L., and Navas, A., Modeling sediment sources and yields in a Pyrenean catchment draining to a large reservoir (Ésera River, Ebro Basin). J. Soil. Sediment. 14 (9), 2014, 1612-1625.

Pimentel, D., Soil erosion: A food and environmental threat. Environment, Development and Sustainability, 8 (1), 2006, 119-137.

Ramos, M.C., Martínez-Casasnovas, J.A., Soil water content, runoff and soil loss prediction in a small ungauged agricultural basin in the Mediterranean region using the Soil and Water Assessment Tool. J. Agr. Sci. 153(3), 2014, 481-496. 
Ribalaygua, J., Pino, M.R., Pórtoles, J., Roldán, E., Gaitán, E., Chinarro, D., Torres, L., Climate change scenarios for temperature and precipitation in Aragón (Spain). Sci. Total Environ. 463-464, 2013, 1015-1030.

Rijckborst, H., Hydrology of the Upper Garonne basin (Valle de Arán, Spain). Leidse, Geol. Meded. 40. 1967, 1-74.

Rostamian, R., Jaleh, A., Afyuni, M., Mousavi, S.F., Heidarpour, M., Jalalian, A., Abbaspour, K.C., Application of a SWAT model for estimating runoff and sediment in two mountainous basins in central Iran. Hydrolog. Sci. J. 53 (5), 2008, 977-988.

Schröter, D., Cramer,W., Leemans, R., Prentice, I.C., Araújo, M.B., Arnell, N.W., Bondeau, A., Bugmann, H., Carter, T.R., Gracia, C.A., de la Vega-Leinert, A.C., Erhard, M., Ewert, F., Glendining,M.,House, J.I., Kankaanpää, S., Klein, R.J.T., Lavorel, S., Lindner,M.,Metzger, M.J.,Meyer, J., Mitchell, T.D., Reginster, I., Rounsevell, M., Sabaté, S., Sitch, S., Smith, B., Smith, J., Smith, P., Sykes, M.T., Thonicke, K., Thuiller, W., Tuck, G., Zaehle, S., Zierl, B., Ecosystem service supply and vulnerability to global change in europe. Science 310 (5752), 2005, 1333-1337.

Stavi, I., Lal, R., Variability of soil physical quality in uneroded, eroded, and depositional cropland sites. Geomorphology 125 (1), 2011, 85-91.

SWAT. SWAT (Soil and Water Assessment Tool): SWAT Model Software, 2011, US Department of Agriculture-Agricultural Research Service, Grassland, Soil \& Water Research Laboratory, Temple, Texas, Available at: http://swatmodel.tamu.edu/software/swat-model/)

Valero-Garcés, B.L., Navas, A., Machín, J., Walling, D., Sediment sources and siltation in mountain reservoirs: a case study from the Central Spanish Pyrenees. Geomorphology 28, 1999, 23-41.

Vicente-Serrano, S.M., Beguería, S., López-Moreno, J.I., García-Vera, M.A., Stepanek, P., A complete daily rainfall database for north-east Spain: Reconstruction, quality control and homogeneity. Int. J. Climatol. 30 (8), 2009, 1146-1163.

Williams, J.R., Chapter 25: The EPIC Model. In: Singh V.P. (Ed), Computer Models of Watershed Hydrology, 1995, Water Resources Publications; Highland Ranch. 
Zhang, X., Srinivasan, R., Debele, B., Hao, F., Runoff Simulation of the Headwaters of the Yellow River Using the SWAT Model With Three Snowmelt Algorithms. J. Am. Water. Resour. As. 44 (1), 2008, 48-61. 